\title{
Combined lower segment cesarean section and cholecystectomy in single sitting-our initial experience
} Tek oturumda kombine alt segment sezaryen ameliyatı ve kolesistektomi-başlangıç
deneyimimiz

\author{
Majid Mushtaque ${ }^{1}$, Ibrahim R. Guru', Tajamul N. Malik ${ }^{2}$, Samina A. Khanday² \\ 'Department of Surgery, Skims Mc Hospital, Bemina, Srinagar, Jammu and Kashmir, India \\ ${ }^{2}$ Department of Health\&Family Welfare, Jammu and Kashmir, India
}

\section{Abstract}

Objective: To study feasibility and results of cholecystectomy at the time of cesarean section.

Material and Methods: Thirty-two patients were subjected to cholecystectomy at cesarean section. Most of them were diagnosed with cholelithiasis at or before the first antenatal scan. Cholecystectomy was performed by subcostal mini-laparotomy, after assessing the anatomy via the cesarean wound.

Results: Cholecystectomy was combined with lower segment cesarean section in all the patients. Under general anaesthesia, surgeries were performed with an mean duration of 90 minutes. Difficult anatomy at calots was found in 3 patients, who required extension of subcostal incision by $3-4 \mathrm{~cm}$. One woman required blood transfusion during operation. There were no other intraoperative or postoperative complications. No extra antibiotics or analgesics doses were needed. Patients were discharged on $5^{\text {th }}-7^{\text {th }}$ postoperative day.

Conclusion: Combined cesarean section and cholecystectomy avoids rehospitalisation for separate cholecystectomy. With an additional small subcostal incision, single anaesthesia, and single hospital stay, the combined procedure confers valuable advantages for both patient and hospital in time, cost, and convenience, including avoiding the separation of mother from newborn entailed by reoperation. It also prevents the possibility of developing acute cholecystitis while the patient is waiting for cholecystectomy. Our results indicate that the combination approach is safe, effective, and well accepted.

(J Turkish-German Gynecol Assoc 2012; 13: 187-90)

Key words: Lower segment cesarean section (LSCS), cholecystectomy, combined approach, gall bladder disease, pregancy

Received: 6 February, 2012

Accepted: 6 June, 2012
Özet

Amaç: Sezaryen ameliyatı sırasında kolesistektominin uygulanabilirliğini ve sonuçlarını incelemek.

Gereç ve Yöntemler: Otuz iki hastada sezaryen ameliyatı sırasında kolesistektomi yapıldı. Hastaların çoğu doğum öncesi ilk tarama sırasında veya öncesinde kolelitiazis tanısı almıştı. Kolesistektomi sezaryen yarası aracılığıyla anatominin değerlendirilmesinden sonra kosta altı mini-laparotomi ile gerçekleştirildi.

Bulgular: Hastaların tamamında kolesistektomi alt segment sezaryen ameliyatı ile kombine edildi. Ameliyatlar, genel anestezi altında, ortalama 90 dakikalık süre içinde yapıldı. Üç hastada "calot"'larda zor anatomi saptandı ve kosta altı kesinin 3-4 cm uzatılması gerekti. Bir kadında ameliyat sırasında kan transfüzyonu gerekti. Bunlar dışında ameliyat sırasında veya sonrasında komplikasyon gözlenmedi. İlave antibiyotik veya analjezik dozları gerekmedi. Hastalar ameliyat sonrası 5.-7. günde taburcu edildi.

Sonuç: Kombine sezaryen ameliyatı ve kolesistektomi, ayrıca kolesistektomi için yeniden hastaneye yatışı önler. İlave küçük bir kosta altı kesisi, tek bir anestezi ve hastaneye bir kez yatış ile kombine işlem; hem hasta hem de hastane için zaman, maliyet ve rahatlık bakımından değerli avantajlar sağlar, anne ve yenidoğan tekrar bir ameliyat sonucu ayrı kalmamış olur. Ayrıca hastanın kolesistektomi için beklerken akut kolesistit geçirme olasılı̆̆ını da önler. Sonuçlarımız kombine yaklaşımın güvenli, etkili ve iyi kabul gördüğünü göstermektedir.

(J Turkish-German Gynecol Assoc 2012; 13: 187-90)

Anahtar kelimeler: Alt segment sezaryen ameliyatı (LSCS), kolesistektomi, kombine yaklaşım, safra kesesi hastalığı, gebelik

Geliş Tarihi: 06 Şubat 2012

Kabul Tarihi: 06 Haziran 2012

\section{Introduction}

Lower segment cesarean section (LSCS) is one of the most common operative procedures in women of reproductive age. Gallstones are three times more common in women than men and cholecystectomy is the most common major operation worldwide. While $2-4 \%$ of pregnant patients are found to have gallstones by obstetric ultrasound, symptomatic cholelithiasis and cholecystitis during pregnancy occur in only five to 10 of every 10.000 births. Most patients are effectively managed with conservative, nonoperative therapy. In some patients, however, surgery is required for refractory symptoms or complications (1). The incidental finding of gallstones has increased considerably as so many patients undergo ultrasound imaging of abdomen for a variety of condition (2). It has been shown that cholecystectomy for gallstones dur- 
ing laparotomy for unrelated condition may sometimes be appropriate because such patients are at greater risk of developing symptoms (3). Many women undergoing gynaecological surgery ask for cholecystectomy to avoid future hospitalization and another operation. One appropriate approach could be to perform combined cesarean section and cholecystectomy in one sitting. A number of procedures have been done at the time of cesarean section, including gynaecological procedures, hernia repair, appendectomy and cholecystectomy (4-7). The combination of cholecystectomy with gynaecologic surgery or cesarean section is virtually undocumented outside of a case report $(8,9)$. This study evaluates the feasibility and results of cholecystectomy at the time of cesarean section in peripheral hospitals where facilities for laparoscopic surgery are lacking.

\section{Material and Methods}

This study was done in the rural hospitals in two districts of Kashmir from June 2007 till Nov 2011. A total of 2210 women were registered for antenatal care. Sixty five patients (2.94\%) were found to have gall bladder disease, either at or before the first antenatal scan, of which 35 women were scheduled for cholecystectomy at the time of cesarean section. Patients who did not agree to a combined procedure or had associated cardiovascular or pulmonary illnesses, acute cholecystitis in third trimester, gall bladder mass and symptoms or investigations suggestive of common bile duct stones were excluded from the study. In our study group, three patients were operated for their gall stone disease in the second trimester of their pregnancy and were also excluded from the study. The remaining 32 patients were either managed conservatively for their symptomatic gallbladder disease or were asymptomatic during their pregnancy. Indications for cesarean section were either cephalo pelvic disproportion (CPD), previous cesarean section, transverse lie, twin pregnancy or placenta praevia. Cholecystectomy was indicated for gall stone disease in the majority of the patients.

Written informed consent was obtained for combined procedures at admission. All patients received prophylactic intravenous antibiotics. Lower segment cesarean section (LSCS) was done first making a Pfannenstiel incision. Upper abdominal anatomy was assessed via the cesarean wound after the uterus was closed. Lax abdominal wall was easily retracted allowing assessment of the upper abdomen. The cesarean wound was closed and followed by a Minilap-cholecystectomy, making a 5 -cm subcostal incision. In case of difficulty, the incision was extended. The common bile duct was not explored in any patient. Closed suction drain was placed in the hepato-renal pouch in selected patients. All the patients were encouraged to be ambulatory a day after the operation.

Data recorded included age, parity, associated illnesses, biliary symptoms, laboratory and radiological investigations, operative procedures, operative findings, intraoperative complications, the time taken for cholecystectomy after completion of cesarean section, postoperative complications, length of hospital stay from the day of operation, mortality and pathological findings of gall bladder.

\section{Results}

The ages of women ranged between 22-40 years. All except three were multigravida. Out of 35 patients planned for cholecystectomy at cesarean section, gall stones with or without sludge was seen in 32 (91.4\%) patients, gall bladder polyps in two (5.7\%) and cholesterosis in one $(2.8 \%)$ of the patient. Patients with gall stone disease had a history of biliary symptoms like episodic upper abdominal pain and/or dyspepsia in $18(56.2 \%)$, acute cholecystitis in early second trimester in 3 (9.3\%), while eleven (34.3\%) women had silent gallstones. All the patients with GB polyp or cholesterosis were asymptomatic. Three patients, who were excluded from the study, were operated in their second trimester for their gallstone disease at a referral centre, as one patient developed empyema of the gall bladder and the remaining two had frequent admissions for their recurrent intractable biliary colic. Other patients with symptomatic gallstones, including those with acute cholecystitis, were managed conservatively during their pregnancy. The indications for LSCS were CPD in 19, previous LSCS in 10, and transverse lie, twin pregnancy and placenta praevia in one each of the patients.

Two patients were operated at 37-38 weeks of pregnancy because of early onset of labour, while the remaining 30 were operated at full term. Under general anaesthesia, lower segment cesarean section (LSCS ) was first done using the Pfannenstiel incision. Anatomy in the upper abdomen was assessed via the cesarean wound after closing the uterus. Three (9.3\%) patients were found to have unfavourable anatomy including dense adhesions, GB lump or contracted intrahepatic gall bladder. Cholecystectomy was completed in all the patients. A 5-cm subcostal incision was used in all the patients. The incision was extended by $3-4 \mathrm{~cm}$ in the women with unfavourable anatomy in the right upper abdomen.

During surgery, adhesions of various intensity were found in 7 patients $(21.8 \%)$, distended gallbladder in 5 (15.6\%), inflamed gallbladder with oedema of wall in 4 (12.5\%), and mucocele in $1(3.1 \%)$ patient. Eight women (25\%) had a contracted thick walled gall bladder suggestive of chronic cholecystitis. None of the patients had empyema of gallbladder, pericholecystic oedema, pericholecystic abscess or common bile duct stones. All the patients had gallstones with or without biliary sludge. Anatomy in the calots triangle was distorted, requiring extension of subcostal incision and cholecystectomy by fundus first method in three (9.3\%) patients. Short cystic duct was encountered in $2(6.2 \%)$ cases, while significant bleeding from the liver bed occurred in $1(3.1 \%)$.

Surgeries were done within a mean operating time of 90 minutes. The mean extra time taken after LSCS for completion of cholecystectomy was 25 minutes (20-35 m). Six women also had bilateral tubal ligation done in the same sitting. Closed suction drain was placed in the hepato-renal pouch in 12 (37.4\%) patients. There were no intraoperative or postoperative complications except for one women who required blood transfusion during the operation. There were no deaths in our series. No extra antibiotics or analgesic doses were needed. Patients were discharged on the $5^{\text {th }}-7^{\text {th }}$ postoperative day. Histopathology of 
the gall bladder specimen showed chronic cholecystitis in 14, acute inflammation in three, benign polyps in three, cholesterosis in one and a normal gallbladder in 11 specimens.

\section{Discussion}

The most common causes of gall bladder disease in pregnancy are gall stones and biliary sludge. The incidence of gall bladder disease in pregnancy is approximately $0.05 \%-0.3 \%$, and asymptomatic gall stones occur in 3.5\%-10\% of all pregnancies. However the need for cholecystectomy occurs in 1 in 1.600 to 1 in 10.000 pregnancies (10-12). Most of the patients with symptomatic gall bladder disease in pregnancy are effectively managed conservatively, and cholecystectomy is performed selectively during the postpartum period (10). Some women require surgery and/or endoscopic retrograde cholangiopancreatography (ERCP) during pregnancy, for refractory symptoms or complications $(1,13)$.

Although gallstone disease in pregnancy is uncommon, the potential maternal and fetal morbidity from both the disease and its surgical therapy are significant. Pregnant patients who develop symptomatic gallstone disease have a high rate of recurrent symptoms (14). After open cholecystectomy, the rate of preterm labour is about $7 \%$ overall and $40 \%$ in the third trimester (15). The rate of spontaneous abortion is $0-18 \%$, and the rate of preterm delivery is $0-22 \%$, depending on the severity of the underlying disease and gestational age (12).

Faced with a pregnant patient with symptomatic gallstone disease, the clinician must decide between operative or nonoperative management. This decision must balance the operative risks against those of the disease itself. The main operative risks include fetal teratogenicity and spontaneous abortion for patients treated early in pregnancy and preterm labour or delivery in those treated in the third trimester. With nonoperative management, the main concern relates to the severity of nausea and/or pain and the potential development of complications of gallstones, including acute cholecystitis, obstructive jaundice, and pancreatitis (14). In this series, 21 out of 32 patients managed non-operatively had documented recurrent symptoms prior to delivery. Three patients who were excluded from the study developed complications prior to delivery and were operated at a referral centre.

If surgery is considered in the pregnant patient, the options include either an open or a laparoscopic approach. Any abdominal operation during pregnancy may adversely affect the fetus and/or mother by several mechanisms. These include direct uterine trauma, altered uteroplacental blood flow, anaesthetic teratogenic effects and altered homeostasis in fetus and mother respectively, increased risk of thromboembolic disease, effects of postoperative medications and increased risk of incisional hernias (16). Laparoscopic surgery has potential advantages compared to open abdominal surgery. These include reduced exposure of the uterus to trauma and air, more rapid maternal recovery and mobilization, decreased maternal dependence on postoperative pain medications, improved operative exposure in some conditions, and decreased risk of incisional hernias (14).
In an era when cost containment in surgery has become increasingly important, a new approach has been combined procedures in laparoscopic surgery as well as open general and gynaecological surgery (17-19). Since we did not have facilities for laparoscopic procedures in all the peripheral hospitals, most of the patients were planned for open cholecystectomy at the time of cesarean section. In our series, ability to perform effectively combined LSCS and minilap-cholecystectomy in selected patients with minimum complications has established the safety of this procedure. There is a paucity of studies on this subject but all previous studies have shown that in selected patients this combined approach can be considered by both the gynaecologists and general surgeons $(8,9)$.

Studies have also shown that cholecystectomy does not increase the morbidity and mortality rates of concomitant gastric, colonic, hepatic, pancreatic and urological surgeries (20). A healthy young patient with no co morbid conditions and uncomplicated cesarean section is a good candidate. Obese patients with co-morbid medical conditions, acute cholecystitis in the third trimester, associated CBD stones, symptoms or investigations suggestive of common bile duct stones and those encountering complications of LSCS would be better served by delayed cholecystectomy. The combined procedure was completed in all the patients in our series.

Fourteen patients in our study were asymptomatic, which included 11 patients with silent stones, two with gall bladder polyp, and one with cholesterosis. Although the latter two are definite indications for cholecystectomy, there is no consensus on management of silent stones. The development of symptoms in silent stones is $2 \%$ per year and morbidity and mortality is approximately equal to those with cholecystectomy (21). So, in patients with silent stones receiving general anaesthesia for other reasons than gall bladder disease, cholecystectomy can be done to avoid complications (4).

The risks of combined surgery are that of longer anaesthesia and operation time, complications of two incisions, increased blood loss and the presence of two visceral peritoneal defects (22). However in our study, it was only 20 - 35 extra minutes for completion of cholecystectomy, and only one patient who had significant bleeding from the liver bed required blood transfusion during surgery. The duration of hospital stay was 5-7 days. No extra antibiotics or analgesia was required. Combined procedure in selected patients, apart from having many advantages, is a cost effective method of treatment, as most of the patients receiving treatment at the rural hospitals are poor.

Combined cesarean section and cholecystectomy avoids rehospitalisation for separate cholecystectomy. With an additional small subcostal incision, single anaesthesia, and single hospital stay, the combined procedure confers valuable advantages for both patient and hospital in time, cost, and convenience, including avoiding the separation of mother from newborn entailed by reoperation. It also prevents the possibility of developing acute cholecystitis while the patient is waiting for cholecystectomy. Our results indicate that the combination approach is safe, effective, and well accepted.

\section{Conflict of interest}

No conflict of interest was declared by the authors. 


\section{References}

1. Kammerer WS. Nonobstetric surgery during pregnancy. Med Clin North Am 1979; 63: 1157-63.

2. Bennett GL, Balthazar EJ. Ultrasound and CT evaluation of emergent gallbladder pathologies. Radiol Clin North Am 2003; 41: 1203-16. [CrossRef]

3. Julian B, Bickerstaff KI, Savage A. Benign diseases of the biliary tract. In: Morris PJ, Malt RA [Eds]. Oxford Textbook of Surgery, Vol 1. Oxford: Oxford University Press 1994; p: 1209-39.

4. Griffin S, Abbassi N, Parveen Z, Zafar A, Ali J. Combined abdominal hysterectomy, cholecystectomy and appendectomy; A study of 25 cases in Abbottabad. J Ayub Med Coll Abbottabad 2006; 18: 57-9 .

5. Bukovsky I, Schneider D, Weinraub Z, Arieli S, Schreyer P, Caspi E. Sterilization at the time of cesarean section: Tubal ligation or hysterectomy? Contraception 1983; 28: 349-56. [CrossRef]

6. Gabriele R, Conte M, Izzo L, Basso L. Cesarean section and hernia repair: simultaneous approach. J Obstet Gynaecol Res 2010; 36: 944-9. [CrossRef]

7. Ochsenbein-Kölble N, Demartines N, Ochsenbein-Imhof N, Zimmermann R. Cesarean section and simultaneous hernia repair. Arch Surg 2004; 139: 893-5. [CrossRef]

8. Pelosi MA, Pelosi MA 3rd, Villalona E. Hand-assisted laparoscopic cholecystectomy at cesarean section. J Am Assoc Gynecol Laparosc 1999; 6: 491-5 . [CrossRef]

9. Pelosi MA 3rd, Pelosi MA, Villalona E. Laparoscopic cholecystectomy at cesarean section. A new surgical option. Surg Laparosc Endosc 1997; 7: 369-72. [CrossRef]

10. Mendez-Sanchez N, Chavez-Tapia NC, Uribe M. Pregnancy and gallbladder disease. Ann Hepatol 2006; 5: 227-30.

11. Sharp HT. Gastrointestinal surgical conditions during pregnancy. Clin Obstet Gynecol 1994; 37: 306-15 . [CrossRef]

12. Kort B, Katz VL, Watson WJ. The effect of nonobstetric operation during pregnancy. Surg Gynecol Obstet 1993; 177: 371-6.

13. Ghumman E, Barry M, Grace PA. Management of gallstones in pregnancy. Br J Surg 1997; 84: 1646-50. [CrossRef]

14. Glasgow RE, Visser BC, Harris HW, Patti MG, Kilpatrick SJ, Mulvihill SJ. Changing management of gall stone disease during pregnancy. Surg Endosc 1998; 12: 241-6.

15. McKellarm DP, Anderson CT, Boynton DJ, Peoples JB. Cholecystectomy during pregnancy without fetal loss. Surg Gynecol Obstet 1992; 174: 465-8.

16. Howard F. Laparoscopic surgery during pregnancy. Chir Int 1995; 2 : 16-22.

17. Pelossi MA, Villalona E. Laparoscopic hysterectomy, appendicectomy and cholecystectomy. N J Med 1993; 90: 207-12.

18. Wadha A, Chowbey PK, Sharma A, Khullar R, Sony V, Baijal M. Combined procedures in laparoscopic Surgery. Surg Laparosc Endosc Percutan Tech 2003; 13: 382-6. [CrossRef]

19. Henley C. Laparoscopic cholecystectomy-hysterectomy-salpingooophorectomy: a combined application of laparoscopic surgery. South Med J 1992; 85: 1266. [CrossRef]

20. Moreaux J. Prospective study of open cholecystectomy for calculous biliary disease. Br J Surg 1994; 81: 116-9. [CrossRef]

21. Gupta SK, Shukla VK. Silent gallstones: a therapeutic dilema. Trop Gastroenterol 2004; 25: 65-8.

22. Murray JM, Gilstrap LC 3rd, Massey FM. Cholecystectomy and abdominal hysterectomy. JAMA 1980; 244: 2305-6. [CrossRef] 